\title{
Information Asymmetry and Capital Structure: A Case Study of Indonesia During 2008-2017
}

\author{
Rahmatania Ekoputri Apriliana, Maria Ulpah*
}

\author{
Department of Management, Universitas Indonesia, Depok, Indonesia \\ *Corresponding author. Email: maria.ulpah@ui.ac.id
}

\begin{abstract}
This research aims to determine the effect of the information asymmetry related to a stock on the capital structure of firms in Indonesia from 2008 to 2017. In this research, five capital structure proxies are used: market leverage, book value of leverage, cost of debt, cost of equity, and the difference between the cost of equity, and the cost of debt. An information asymmetry variable was measured with stock liquidity computed using the Amihud illiquidity ratio measure. This research uses the panel data generalized least squares method, with a pooled least squares, and fixedeffect model. The result shows that information asymmetry has a positive and significant effect on Indonesian firms' capital structures, which indicates that an increase in information asymmetry can increase firms' leverage.
\end{abstract}

Keywords: Information Asymmetry, Stock Liquidity, Capital Structure, Leverage, Indonesia, Amihud

\section{INTRODUCTION}

The capital structure of a firm has been an ongoing topic for more than fifty years. In the discussion about this topic, two questions are often raised: whether capital structure matters and, if so, the factors that affect the optimum combination of this debt and equity financing. However, until now, no clear, non-ambiguous answers have been found for these preceding questions regarding capital structure (Megginson, 1997). Several studies were conducted to determine the optimum debt and equity combination in Indonesia. According to Tandya (2015), the factors that influence the selection of the capital structure in Indonesia are profitability, company size, and opportunity growth, with negative relationships for all three factors. Santi (2003) stated that the capital structure is positively determined by asset tangibility and company size, as well as negative profitability and growth opportunities. Previous studies indicated that these factors are the focus of the discussions on capital structure in Indonesia.

Turning to the relevance of capital structure, Modigliani and Miller (1958) stated that financing decisions and risks do not affect company value if both of the following assumptions are met: the company's total cash flow is not affected by these decisions and markets are perfect. This "perfect markets" assumption mean that the existence of taxes, bankruptcy costs, agency costs, and information asymmetry are not considered. When implemented in the real world, information asymmetry in the market and its relationship to capital structure cannot be ignored. According to Myers and Majluf (1984), through the presentation of the pecking order theory, the companyby selecting certain financing types-considers its sensitivity to the information asymmetry condition. In this theory, companies choose financing with a low cost of information asymmetry. In general, companies prefer internal funding sources first, then move on to external financing sources. In the category of external financing, the company prefers to seek out debt financing first. If funds remain insufficient, then the company resorts to its last option of equity financing, which has a higher cost of information asymmetry.

Many studies have attempted to determine the main components of the pecking order theory. Shyam-sunder and Myers (1999) determined that this theory was a good enough measure for determining corporate financing behavior. The results of Shyam-sunder and Myers (1999) the study of were further examined in Fran and Goyal (2003), and Fama and French (2001), where they stated that who found that the pecking order theory does not always follow the theory of the actual market. In their studies, a new pecking order theory was expected to be in line with market conditions if implemented in markets with high information asymmetry problems. 
This research was conducted using a sample of companies listed on the Indonesia Stock Exchange (IDX) for several reasons. The first reason is that the researchers are from Indonesia, and not many studies exist that further investigate the relationship between information asymmetry and corporate capital structures in Indonesia, and Indonesia fulfills the characteristics of an emerging market. These characteristics include below average per capita income-Indonesia's is $\$ 4,035$ according to the World Bank (2019)—high economic growth-Indonesia's is $5.2 \%$, higher than the world average of $3.3 \%$ (IMF, 2018) - high volatility, with many social, and environmental problems affecting Indonesia; capital markets that have not developed like those in developed countries; and an above average rate of return for investors, in line with the high economic growth. Therefore, Indonesia is categorized as an emerging market.

In emerging markets, the level of information asymmetry is relatively higher than capital markets in clothing countries because of one characteristic of emerging markets that was previously mentioned before: undeveloped capital market structures (Salehi and Biglar, 2014). In addition, emerging markets are also riskier; therefore, markets in emerging market countries also have a higher expected return than developed countries. This causes a negative effect of causing emerging markets to be more strongly affected during times of high world market volatility. When the market becomes volatile, uncertainty increases, which biases information that reaches investors, and the result is an increase in information asymmetry (de Wet, 2004).

Increased information asymmetry makes investors demand that the company provide a higher risk premium, which in turn makes the company prefer debt financing, according to the pecking order theory. This choice increases the company's market leverage. In the Indonesian market, one company seems to follow the pattern of the pecking order theory-PT Ades Waters Indonesia. The liquidity and market leverage of PT Ades Waters Indonesia is further observed. In this discussion, liquidity is a benchmark for information asymmetry. When the liquidity of a stock is low, investors trade not based on liquidity motives but because they have certain information that other investors do not have (Easley, Hvidkjaer, and O'Hara, 2010), thus creating information asymmetry. Over time, lower liquidity signals the presence of information asymmetry, and the company's market leverage increases because companies prefer debt to equity financing. This study seeks to determine whether the phenomenon at PT Ades Waters Indonesia that reflected the pecking order theory also occurred at other companies listed on the IDX.

\section{THEORETICAL BASIS}

\subsection{Capital Structure}

Capital structure is a specific combination of longterm debt and equity used by companies to finance their operational activities (Ross, Westerfield, and Jordan, 2010). The company focuses on two aspects of its capital structure. The first is how much debt it must carry and the proportion of debt and equity that is optimal. This proportion is important because it affects the company's value (Ruan, Tian, and Ma, 2011). The second aspect is the type of financing that is less expensive for the company (see the cost of capital from financing).

Firms need financing to fund their activities, and financing can occur in two forms: debt and equity. Debt financing is financing from third parties outside the owner and the manager. The company is obliged to pay debts and interest during certain periods to third parties, and the collateral takes the form of its assets if it fails to pay. This type of financing can be in the form of longterm debt and bonds, short-term debt, and leases. Equity financing refers to financing the company's ownership, which is characterized by its shareholdings. In return, the company provides rewards in the form of tax-free income distributions - commonly called dividends - to shareholders. In essence, when the company has debt, its owner is represented by its shareholders who are responsible for the debt. Therefore, interest payments to creditors take precedence over paying dividends to shareholders, and shareholders become residual claimants.

The highlight of this research is the pecking order theory. This theory arises as a result of the existence of information asymmetry in financial markets, namely, when managers have more information about the condition of a company than outside investors. Apart from the existence of transaction costs when issuing company shares, also admitted is that information costs appear because information asymmetry exists, undervaluing newly issued securities on the market. This often happens with new equity financing. Therefore, companies often choose not to carry out projects with the potential to be profitable if, in the end, they must be financed with risky financial instruments (Myers and Majluf, 1984). In this situation, the pecking order theory predicts that there is a sequence in corporate financing that is based on funding sources that are least sensitive to information costs and that have the lowest risk. Companies prefer internal financing, then short-term debt, then long-term debt, and finally equity, which is the financing type with the highest information cost (Myers and Majluf, 1984; Donaldson, 1961). 


\subsection{Information Asymmetry}

The efficient market hypothesis states that the price of an asset in the market must fully reflect all relevant information on that available asset (Fama, 1970; Fama, 1991).. In the capital market, relevant information is information that can affect a company's future cash flows. In an efficient market, the price of an asset is a good signal of resource allocation because the information available is symmetrical (Fama, 1970).

The effect of the existence of information asymmetry in the market was first described by the lemon market theory (Akerlof, 1970)]. The effect of information asymmetry in this theory is portrayed by the used car market in the United States. In this market, old and damaged cars are called lemons. Buyers in this market purchase a car without knowing whether the car is good or bad, meaning that prices in this market are the averages of the condition of all cars in the marketsome are good and some are bad. However, the seller certainly has more information about the actual condition of the car.

In the capital market, information asymmetry between borrowers and lenders is inevitable because borrowers likely have more information about their projects that require funds-known as parties with "insider" information - than lenders (Leland and Pyle, 1977). Another assumption is that lenders must have the characteristics of the borrower as a whole. However, the moral hazard problem, which is mentioned in agency theory (Jenson and Meckling, 1976), complicates the transfer of information between parties in the market.

This also occurs in secondary markets such as the capital market, where buyers of shares are divided into two (Abad-Diaz and Rubia, 2005). There are those who trade for liquidity purposes and only use uninformed trader information; others trade because they have information that results in gains even though it is not fully visible by informed traders (Easley, Hvidkjaer, and O’Hara, 2002).

The role of information asymmetry in corporate financing decisions can be traced to the earliest work by (Myers and Majluf, 1984). According to the pecking order theory and investors, equity financing is a more sensitive source of funds regarding information than debt financing, which is far less sensitive to information asymmetry. Therefore, considering adverse selection, outside investors require a higher risk premium selection to overcome this issue relative to lenders. Therefore, companies with high information asymmetry tend to be more indebted and ultimately have high leverage (Fama and French, 2015).

The following research hypotheses are developed to achieve the research objectives.
H1: Information asymmetry has a positive effect on market leverage.

$\mathrm{H} 2$ : Information asymmetry has a negative effect on the book value of leverage.

H3: Information asymmetry has a positive effect on the cost of debt.

H4: Information asymmetry has a positive effect on the cost of equity.

H5: Information asymmetry has a positive effect on the difference between the cost of equity and the cost of debt.

\section{DATA AND VARIABLES}

\subsection{Sample Selection}

This research used the population of companies in Indonesia that are listed on the IDX from 2008 to 2017. Firms operating in the financial sector are not included in the sample because high leverage is considered normal for these companies, whereas high leverage in non-financial companies mostly indicates financial distress (Fama and French, 1992).. Firms in the utility sector (sector 7 in Indonesia Stock Exchange) are also excluded because of the heavy regulation aspect within this sector (Kahle and Walkling, 1996). Furthermore, firms that lack complete financial data and that have a history of being suspended by the IDX are also excluded from this research. A total of 258 companies are included in the sample.

\subsection{Variables}

The descriptive statistics for all variables included in the study can be found under Table I. We include five aspects of capital structure that are dependent variables in this research. These variables are market leverage (MarketLev), book value of leverage (BookLev), cost of debt (COD), cost of equity (COE), and the difference between the cost of equity and the cost of debt (COECOD). MarketLev is computed by dividing total debt by the market value. BookLev is the ratio of longterm debt to total debt. COD is calculated as interest expense divided by total debt. COE is calculated using the capital asset pricing model by Sharpe (1964). Finally, COECOD is COE minus COD.

The only independent variable in this study is information asymmetry (InfAsy). To calculate InfAsy, we use the Amihud illiquidity ratio (Amihud, 2002). The Amihud ratio calculates the liquidity of the data that cover a long period, and is as follows:

$$
I_{L L I Q_{i, t}}=\frac{1}{D} \sum_{t=1}^{D} \frac{\left|r_{t}\right|}{V O L_{t}}
$$


where $\mathrm{D}$ is the number of days, on which the stock is traded in a year, VOL is the volume of shares traded on day $t$, and $\left|r_{t}\right|$ is the absolute return of the stock. However, according to Edmans, Fang, and Zur (2013), the distribution of the Amihud illiquidity ratio is very positively skewed. Therefore, the researcher further processes the ILLIQ proxy by taking its natural logarithm and then multiplying it by -1 , indicating that a high InfAsy translates to high liquidity. This condition results in the InfAsy proxy as follows:

$$
\operatorname{Inf} A s y=-\ln \left(1+I L L I Q_{i, t}\right)
$$

Table I. Descriptive Statistics

\begin{tabular}{|l|c|c|c|c|c|}
\hline Variables & Mean & $\begin{array}{c}\text { Std. } \\
\text { Dev }\end{array}$ & Max. & Min. & Obs. \\
\hline MarketLev & 0.2213 & 0.2166 & 1.5722 & 0 & 2,573 \\
\hline BookLev & 0.3918 & 0.3609 & 1.3020 & 0 & 2,576 \\
\hline COD & 0.1821 & 1.8163 & 57.1516 & 0 & 2,571 \\
\hline COE & 0.2058 & 0.2627 & 2.0851 & 0.0008 & 1,966 \\
\hline COECOD & -0.0702 & 1.8443 & 2.0725 & -57.0961 & 2,567 \\
\hline InfAsy & -1.2855 & 1.5451 & 0 & -6.5468 & 2,532 \\
\hline Tang & 0.3556 & 0.2331 & 1.2573 & 0 & 2,577 \\
\hline Size & 21.1888 & 1.7778 & 26.4124 & 13.7113 & 2,759 \\
\hline ROA & -0.0006 & 2.2406 & 15.4777 & -112.4766 & 2,759 \\
\hline MTB & 1.7744 & 2.9620 & 80.3861 & 0.0201 & 2,577 \\
\hline DAR & 0.3365 & 3.3275 & 162.862 & 0 & 2,579 \\
\hline Rate & 12.5433 & 0.9701 & 14.498 & 11.073 & 2,580 \\
\hline
\end{tabular}

We also include variables specific to each firm that have revealed their effects on the capital structure and cost of capital as control variables. Asset tangibility (Tang) is defined as net property, plant, and equipment divided by total assets. Firm size (Size) is computed as the natural logarithm of total assets. Profitability is defined as the return on assets (ROA) or net income over total assets. The market-to-book (MTB) ratio, which shows the opportunity for growth, is computed as total assets minus book equity plus market capitalization divided by total assets. The debt-to-asset ratio (DAR) is total debt divided by total assets. The bank lending rate (Rate) is proxied by the interest rate set by the Indonesian central bank - the Bank Indonesia rate.

\section{Results and Analysis}

\section{Panel Regression Model}

This research investigates the effect of the independent variable InfAsy on the dependent variables MarketLev, BookLev, COD, COE, and COECOD for values of Tang, Size, ROA, MTB, DAR, and Rate. Because five dependent variables are studied, this research uses five models. For the market leverage, book value of leverage, and COE variables, we use a firm fixed-effect model for the linear regression. The COD and the difference between the COE and debt use pooled regression models. These models were determined using the Chow test, the Breusch-Pagan Lagrange Multiplier test, and the Hausman test.

The models used to test the hypotheses developed are as follows:

$$
\begin{aligned}
\text { MarketLev }_{i, t} & =\alpha+\beta_{1,1} \text { InfAsy }_{i, t}+\beta_{2} \text { Tang }_{i, t}+\beta_{3} \text { Size }_{i, t} \\
& +\beta_{4} \text { ROA }_{i, t}+\beta_{5} \text { MTB }_{i, t}+\varepsilon_{i, t}
\end{aligned}
$$

$$
\begin{aligned}
\text { BookLev }_{i, t}= & \alpha+\beta_{1,2} \text { InfAsy }_{i, t}+\beta_{2} \text { Tang }_{i, t}+\beta_{3} \text { Size }_{i, t} \\
& +\beta_{4} \text { ROA }_{i, t}+\beta_{5} \text { MTB }_{i, t}+\varepsilon_{i, t} \\
\text { COD }_{i, t}=\alpha+ & \beta_{1,3} \text { InfAsy }_{i, t}+\beta_{2} \text { Tang }_{i, t}+\beta_{3} \text { Size }_{i, t} \\
& +\beta_{4} \text { ROA }_{i, t}+\beta_{5} \text { MTB }_{i, t}+\beta_{6} \text { DAR }_{i, t} \\
& +\beta_{7} \text { Rate }_{i, t}+\varepsilon_{i, t} \\
\text { COE }_{i, t}=\alpha+ & \beta_{1,4} \text { InfAsy }_{i, t}+\beta_{2} \text { Size }_{i, t}+\beta_{3} \text { MTB }_{i, t} \\
+ & \beta_{4} \text { DAR }_{i, t}+\varepsilon_{i, t}
\end{aligned}
$$

The control variables include Tang, Size, ROA, MTB, DAR, and Rate, as previously discussed. Because heteroskedasticity and autocollinearity conditions arise in these models, all of the models were regressed using robust standard errors to correct the deviations in the classical assumptions. 
Table II. Regression Results

\begin{tabular}{|c|c|c|c|c|c|}
\hline & (1) & (2) & (3) & (4) & (5) \\
\hline & FE & FE & Pooled & FE & Pooled \\
\hline Inf & $0.0045 *$ & -0.0041 & 0.0006 & $0.0065 * * *$ & $0.0068 * * * *$ \\
\hline Asy & $(0.0026)$ & $(0.0059)$ & $(0.0007)$ & $(0.0019)$ & $(0.0022)$ \\
\hline \multirow{2}{*}{ Tang } & $0.1428 *$ & $0.1385^{*}$ & -0.0047 & & 0.0105 \\
\hline & $(0.0734)$ & $(0.0787)$ & $(0.0047)$ & & $(0.0145)$ \\
\hline \multirow{2}{*}{ Size } & $0.0186 * * *$ & $0.0429 * * *$ & 0.0000 & $0.0054 * * *$ & $0.0060 * * *$ \\
\hline & $(0.0058)$ & $(0.0165)$ & $(0.0007)$ & $(0.0018)$ & $(0.0021)$ \\
\hline \multirow{2}{*}{ ROA } & $-0.1433 * * *$ & 0.0415 & $-0.0224 * *$ & & $0.0612^{* *}$ \\
\hline & $(0.0371)$ & $(0.0698)$ & $(0.0090)$ & & $(0.0276)$ \\
\hline \multirow{2}{*}{ MTB } & -0.0031 & -0.0003 & -0.0005 & 0.0006 & -0.0004 \\
\hline & $(0.0036)$ & $(0.0024)$ & $(0.0004)$ & $(0.0010)$ & $(0.0012)$ \\
\hline \multirow{2}{*}{ DAR } & & & $-0.0054 *$ & -0.0030 & 0.0147 \\
\hline & & & $(0.0033)$ & 0.0085 & $(0.0101)$ \\
\hline \multirow{2}{*}{ Rate } & & & $0.0027 * *$ & & $0.0171 \% * *$ \\
\hline & & & $(0.0011)$ & & $(0.0035)$ \\
\hline \multirow{2}{*}{ Cons } & -0.2194 & -0.5765 & 0.0385 & -0.1973 & -0.3190 \\
\hline & $(0.1203)$ & $(0.3456)$ & $(0.0222)$ & $(0.0579)$ & $(0.0685)$ \\
\hline Adj. $\mathbf{R}^{2}$ & $14.39 \%$ & $14.25 \%$ & $0.53 \%$ & $2.06 \%$ & $0.21 \%$ \\
\hline Obs & 2,526 & 2,525 & 2,520 & 2,409 & 2,515 \\
\hline \multicolumn{6}{|l|}{ Note: } \\
\hline
\end{tabular}

The regression results are presented in Table II. Using InfAsy as the independent variable, the dependent variables are listed in five columns. Column (1) indicates MarketLev, column (2) indicates BookLev, column (3) indicates COD, column (4) indicates COE, and column (5) indicates (COECOD).

Out of all of the models, models (1), (4), and (5) yield significant and positive relationships between information asymmetry, and each dependent variable. In column (1), the significant result means that market leverage is positively affected by information asymmetry. Therefore, when facing a more serious adverse selection problem, a firm has the preference of using more debt, which is in line with $\mathrm{H} 1$; thus, this research supports H1. Most of the control variables in this column also yield significant results and bear the expected signs. Firms with a larger proportion of tangible assets have higher market leverage because tangible assets can affirm creditors when taking on debt financing. Larger firms take on more debt because they present a lower probability of bankruptcy and, thus, lower financial distress costs. In contrast, profitability is inversely related to leverage because firms that are profitable prefer to retain their earnings to avoid the asymmetric information costs associated with external financing.

Column (4) shows significant results, indicating that the $\mathrm{COE}$ is positively affected by information asymmetry, supporting H4. This result is consistent with the pecking order theory that states that the $\mathrm{COE}$ is more sensitive to firms' information condition than the COD because investors need higher risk premiums to compensate for the gap in information between them and firms' managers (Myers and Majluf, 1984). However, only one control variable-firm sizesignificantly affects the COE. This finding is different from the results in Gao and Zhu (2015), where firm size was found to have a relationship in the opposite direction of the COE.

Column (5) also yields significant results, showing that the difference between the COECOD is positively affected by information asymmetry, supporting H5. Therefore, information asymmetry has positive effects on increasing both the COECOD. This finding is in line with the previous result that the $\mathrm{COE}$ is more sensitive to a firm's information environment than the COD, although both increase accordingly with information asymmetry. However, column (5) also shows contrasting results in terms of the control variables, where both Size and ROA are positively related to differences between the COECOD. The findings from Gao and Zhu (2015)indicated the opposite result, where Size and ROA a have negative impact in model (5).

Columns (2) and (3) yield insignificant results, showing that information asymmetry has no predictive power in explaining a firm's book value of leverage and COD, which rejects $\mathrm{H} 2$ and $\mathrm{H} 3$. Despite this result, the expected sign for these two models is still consistent with Gao and Zhu (2015). Model (2) yields a negative result, indicating that information asymmetry causes a firm to prefer short-term debt over long-term debt, and model (3) yields a positive result, indicating that information asymmetry also increases the COD attributed in debt financing, although not as significantly as it affects the COE. In column (2), Tang and Size are positively significant in explaining the book value of leverage. This result is consistent because larger firms and firms with higher tangible assets tend to be more confident in undertaking long-term debt (Barclay and Smith, 1995). Meanwhile, column (3) shows significant results for ROA, DAR, and Rate. More profitable firms have a lower tendency to go bankrupt; therefore, they are attributed to a lower COD, yielding in a negative relationship with ROA. 
Furthermore, DAR shows the degree, to which firms finance their assets using debt, and firms prefer to use more debt when the COD is relatively low. The positive relationship of the lending rate with the COD is as expected because, given Bank Indonesia's setting of expectations for interest rates, the interest rate on the debt that must be paid to banks also increases accordingly.

\section{CONCLUSION}

This research aimed to determine the effect of information asymmetry on capital structure for firms operating in Indonesia from 2008 to 2017. From the results, we find evidence that information asymmetry has a positive and significant relationship with market leverage, COE, and the difference between the COECOD. Information asymmetry also has an insignificant result on a firm's book value of leverage and COD. This finding indicates that, despite the insignificance of this result from two aspects, information asymmetry still has a notable effect on a firm's capital structure, especially on leverage. This finding also confirms that the pecking order theory holds for firms in Indonesia because they issue more debt when faced with information asymmetry and must present higher rates of returns for investors because investors demanded a higher risk premium when an information gap exists with the firm's manager.

The control variables tangibility, size, profitability, market-to-book ratio, debt-to-asset ratio, and rate have varying effects on each dependent variable. However, none of the control variables have a significant relationship in all of the models because they are only significant in several models but not all. These results indicate that, despite being included in the research as variables to control the model, they do not have a strong enough effect on all aspects of capital structure.

\section{REFERENCES}

[1] Abad-Diaz D, Rubia A (2005) Modelos de estimación de la probabilidad de negociación informada: una comparación metodológica en el mercado español

[2] Akerlof GA (1970) The Market for "Lemons": Quality Uncertainty and the Market Mechanism. Q J Econ 84:488-500. doi: 10.2307/1879431

[3] Amihud Y (2002) Illiquidity and Stock Returns: Cross-Section and Time-Series Effects. J Financ Mark 5:31-56. doi: 10.2139/ssrn.3139180

[4] Barclay MJ, Smith CW (1995) The Maturity Structure of Corporate Debt. J Finance 50:609631. doi: $10.2307 / 2329421$
[5] de Wet WA (2004) The Role of Asymmetric Information on Investments in Emerging Markets. Econ Model 21:621-630. doi: 10.1016/j.econmod.2003.09.002

[6] Donaldson G (1961) Corporate Debt Capacity; a Study of Corporate Debt Policy and The Determination of Corporate Debt Capacity. Division of Research, Graduate School of Business Administration, Harvard University, Boston

[7] Easley D, Hvidkjaer S, O’Hara M (2002) Is Information Risk a Determinant of Asset Returns? J Finance 57:2185-2221. doi: 10.1111/15406261.00493

[8] Easley D, Hvidkjaer S, O’Hara M (2010) Factoring Information into Returns. J Financ Quant Anal 45:293-309. doi: 10.2139/ssrn.556079

[9] Edmans A, Fang VW, Zur E (2013) The Effect of Liquidity on Governance. Rev Financ Stud 26:1443-1482. doi: 10.1093/rfs/hht012

[10] Fama EF (1991) Efficient Capital Markets: II. J Finance 46:1575-1617. doi: 10.2307/2328565

[11] Fama EF, French KR (1992) The Cross-Section of Expected Stock Returns. J Finance 47:427-465. doi: 10.1111/j.1540-6261.1992.tb04398.x

[12] Fama EF, French KR (2001) Disappearing Dividends: Changing Firm Characteristics or Lower Propensity to Pay? J Financ Econ. 60: 3-43. doi: 10.1016/S0304-405X(01)00038-1

[13] Fama EF, French KR (2015) Testing Trade-Off and Pecking Order Predictions about Dividends and Debt. Rev Financ Stud 15:1-33. doi: $10.1093 / \mathrm{rfs} / 15.1 .1$

[14] Frank MZ, Goyal VK (2003) Testing the Pecking Order Theory Of Capital Structure. J Financ Econ 67:217-248. doi: 10.1016/S0304-405X(02)00252-0

[15] Gao W, Zhu F (2015) Information Asymmetry and Capital Structure Around the World. Pacific Basin Financ J 32:131-159. doi: 10.1016/j.pacfin.2015.01.005

[16] Jensen MC, Meckling WH (1976) Theory of the Firm: Managerial Behavior, Agency Costs and Ownership Structure. J Financ Econ 3:305-360. doi: 10.1016/0304-405X(76)90026-X

[17] Kahle KM, Walkling RA (1996) The Impact of Industry Classifications on Financial Research. J Financ Quant Anal 31:309-335. doi: $10.2307 / 2331394$

[18] Leland HE, Pyle DH (1977) Informational Asymmetries, Financial Structure, and Financial 
Intermediation. $\mathrm{J}$ Finance 32:371-387. doi: $10.2307 / 2326770$

[19] Malkiel BG, Fama EF (1970) Efficient Capital Markets: A Review of Theory and Empirical Work. J Finance 25:383-417. doi: 10.1111/j.15406261.1970.tb00518.x

[20] Megginson WL (1997) Corporate Finance Theory. Addison-Wesley

[21] Modigliani F, Miller MH (1958) The Cost of Capital, Corporation Finance and the Theory of Investment. Am Econ Rev 48:261-297 doi: 10.1136/bmj.2.3594.952

[22] Myers SC, Majluf NS (1984) Corporate Financing and Investment Decisions When Firms have Information that Investors Do Not have. J Financ Econ 13:187-221

[23] Ross, Westerfield, Jordan (2010) Fundamentals of Corp. Finance

[24] Ruan W, Tian G, Ma S (2011) Managerial Ownership, Capital Structure and Firm Value:
Evidence from China's Civilian-run Firms. Australas Account Bus Financ J 5:73-92.

[25] Salehi M, Biglar K (2014) Study of the Relationship between Capital Structure Measures and Performance: Evidence from Iran. Int J Bus Manag 4:97-103doi: 10.5539/ijbm.v4n1p97

[26] Santi F (2003) Determinants of Indonesian Firms' Capital Structure. J Ekon dan Bisnis Indones 18:243-260

[27] Sharpe WF (1964) Capital Asset Prices: A Theory of Market Equilibrium under Conditions of Risk. J Finance 19:425-442. doi: 10.2307/2329297

[28] Shyam-sunder L, Myers SC (1999) Testing Static Tradeoff Againts Pecking Order Models of Capital Structure. J Financ Econ 51:219-244. doi: 10.1016/S0304-405X(98)00051-8

[29] Tandya C (2015) The Capital Structure Determinants of Indonesia Publicly Listed Firms. iBuss Manag 3:19-27 